\title{
EFFECT OF TAPER WITH THREADED TOOL PROFILE ON MECHANICAL AND MICROSTRUCTURAL PROPERTIES OF FRICTION STIR WELDED 5083 ALUMINIUM ALLOY
}

\author{
P.Satish Kumar ${ }^{1}$, Ch.S.R.Sastry ${ }^{2}$, A.Devaraju ${ }^{3}$, M.Shiva Chander ${ }^{4}$ \\ ${ }^{I}$ Research Scholar, Department of Mechanical Engineering, Kakatiya University, Telangana, India \\ ${ }^{2}$ Professor in Mechanical Engineering Department, Kakatiya Institute of Technology \& Science, Telangana, India \\ ${ }^{3}$ Associate Professor in Mechanical Engineering Department, SR Engineering College, Telangana, India \\ ${ }^{4}$ Assistant Professor in Mechanical Engineering Department, SR Engineering College, Telangana, India
}

\begin{abstract}
A study was prepared of weldability of 4mm-thick aluminium alloy 5083 plates by friction stir welding. The arrangement of experiments was prepared based on ability of universal milling machine and where different tool rotations speeds $900 \mathrm{r} / \mathrm{min}$, $1120 \mathrm{r} / \mathrm{min}, 1400 \mathrm{r} / \mathrm{min}$ and $1800 \mathrm{r} / \mathrm{min}$, the welding speed is at $40 \mathrm{~mm} / \mathrm{min}$ were taken. Analysis is made with the threaded profile tool. Samples for microstructure analysis, Vickers micro-hardness measurements and tensile-testing samples were prepared. It was observed that the better mechanical properties were achieved at moderate tool rotational speed, and equi-axed grains obtained at threaded profile tool, grain size were obtained half of the base material.
\end{abstract}

Keywords: Friction-stir welding, AA 5083, tool revolving speed, mechanical properties, threaded profile tool.

\section{INTRODUCTION}

The 5083 aluminium alloy is revealed good corrosion resistance to seawater, and improved mechanical properties. It has good formability, machinability and weldability. The 5083 aluminium alloy is used for providing of welded components for shipbuilding and railway vehicles. It has the premier strength of the non-heat treatable alloys. ${ }^{[1-}$ 2] It is not recommended for use in temperatures in excess of $65^{\circ} \mathrm{C}$ to a corrosive environment. ${ }^{[3]}$ Many studies were made on the weld ability of 5083 aluminium alloy. ${ }^{[4-6]}$ Aluminium alloys are friction-stir processed (FSP) then the properties of super plastic are obtained, as a consequence of grain refinement. ${ }^{[7]}$ Friction stir processing (FSP) is used to convert a heterogeneous microstructure to a more homogeneous, developed microstructure before not reaching its melting temperature. Welding is a method for joining different metals or materials. In order to join two or more pieces of metal through any welding process, the most indispensable requirement is heat. Pressure may also be in employment but in many processes, is not important. There are more than forty different welding processes, which can be broadly divided in two group's viz. fusion welding and solid welding.

Friction Stir Welding is a solid state joining process invented at the Welding Institute (TWI) in 1991.

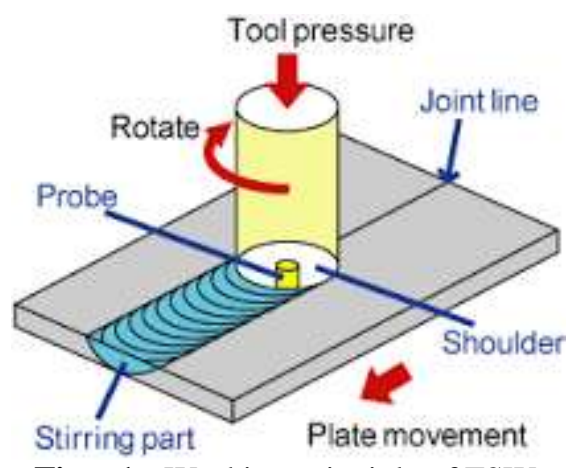

Fig - 1: Working principle of FSW

Table-1: Base metal Properties of 5083 alloy

\begin{tabular}{|l|l|l|l|}
\hline Material & Density & UTS $\left(\mathrm{N} / \mathrm{mm}^{2}\right)$ & Yield strength $\left(\mathrm{N} / \mathrm{mm}^{2}\right)$ \\
\hline AA5083 & 2.66 & 240 & 135 \\
\hline
\end{tabular}

\section{LITERATURE REVIEW}

Lombard et al., (2008) in this research work present a methodical loom to optimizing FSW process parameters (tool revolving speed and feed rate). Eleven experiments were conducted by varying the tool revolving speed as well as welding speed. The tensile strength of the joint was increased from 289 to $313 \mathrm{MPa}$ by varying the tool rotational speed from $400 \mathrm{rpm}$ to $200 \mathrm{rpm}$ at the invariable welding speed of $85 \mathrm{~mm} / \mathrm{min}$. The tensile strength of the joint increased from $254 \mathrm{MPa}$ to $315 \mathrm{MPa}$ by varying the tool rotational speed from $635 \mathrm{rpm}$ to $254 \mathrm{rpm}$ at the constant welding speed $135 \mathrm{~mm} / \mathrm{min}$. The work indicates that the tool rotational speed is the key parameter governing the tensile strength. 
Han, Lee, Park, Ko, Woo and Kim et al., (2007) evaluated the mechanical properties of friction stir welds while varying process parameters in 5083-O aluminum alloy. Their tool had a shoulder diameter of $20 \mathrm{~mm}$, a threaded pin with a length, diameter, and thread pitch of $4.5,5.0$, and $2.0 \mathrm{~mm}$ respectively. The tool was made from SK tool steel, tilted at $2^{0}$, and had a plunging depth of 4.5-4.7 $\mathrm{mm}$. Welds were done at 500, 800, $1800 \mathrm{rpm}$ and 124, 267, $342 \mathrm{~mm} / \mathrm{min}$. Tensile tests were performed on all welds. The welds performed at $500 \mathrm{rpm}$ and $800 \mathrm{rpm}$ showed a reduction in quality as the traverse feed increased. At $1800 \mathrm{rpm}$, all weld speeds produced defects. In turn, these welds exhibited very low quality mechanical properties. All fractures during tensile testing occurred in the stir zone. The optimum FSW parameters for this experiment were $800 \mathrm{rpm}$ and 124 $\mathrm{mm} / \mathrm{min}$ which had an ultimate tensile strength around 350 $\mathrm{MPa}$.

\section{EXPERIMENTAL PROCEDURE}

\subsection{Material}

The plates of $4 \mathrm{~mm}$ thickness AA5083 aluminium alloy were slice into size $150 \mathrm{~mm}$ x $60 \mathrm{~mm}$ and machined with square butt joint pattern. The initial pattern was obtained by securing the plates in butt location using in particular designed and fabricated fixture. Welding was carried out in a single pass using non-consumable tools made of High Speed steel. The chemical composition of the AA5083 substance used in the present study is given in Table II.

Table-2: Chemical Composition of AA5083 in wt \%

\begin{tabular}{|l|l|l|l|l|l|l|l|l|l|}
\hline Material & $\mathrm{Mg}$ & $\mathrm{Mn}$ & $\mathrm{Si}$ & $\mathrm{Cr}$ & $\mathrm{Fe}$ & $\mathrm{Zn}$ & $\mathrm{Ti}$ & $\mathrm{Cu}$ & $\mathrm{Al}$ \\
\hline AA5083 & 4.5 & 0.7 & 0.4 & 0.15 & 0.4 & 0.25 & 0.15 & 0.1 & Rest \\
\hline
\end{tabular}

\subsection{FSW}

The welding was carried out in a universal milling machine with varying tool rotation speeds. The tool, viz conical threaded with cylindrical shoulder, is used to fabricate the joints. Based on the literature, with ease of use of speeds on the machine, 4 different revolving speeds were chosen to bring out the experimentation. The welding parameters and tool proportions are as shown in Tabular column III.

Table - 3: FSW Process Parameters

\begin{tabular}{|l|l|}
\hline Values/Types & Process Parameter \\
\hline Material used & AA5083 \\
\hline Type of joint & Butt joint \\
\hline $\begin{array}{l}\text { Thickness of the material } \\
\text { in } \mathrm{mm}\end{array}$ & 4 \\
\hline Tool rotation speed $(\mathrm{rpm})$ & $900,1120,1400$ and 1800 \\
\hline Traverse speed in $\mathrm{mm} / \mathrm{min}$ & 40 \\
\hline Length of weld in $\mathrm{mm}$ & 75 \\
\hline Axial load in KN & 5 \\
\hline
\end{tabular}

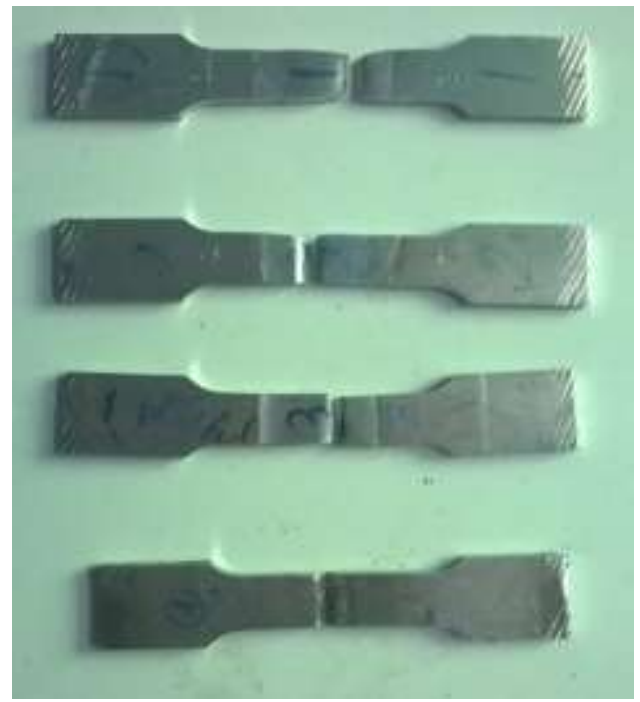

Fig-2: Tensile test specimens

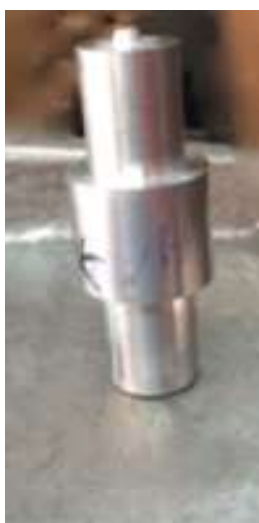

Fig - 3: Conical threaded profile tool geometry

The typical EN-AW 5083 aluminium alloy with composition in mass fraction: $4.3 \% \mathrm{Mg}, 0.52 \% \mathrm{Mn}, 0.147 \% \mathrm{Si}, 0.087 \% \mathrm{Cr}$, $0.282 \% \mathrm{Fe}, 0.21 \% \mathrm{Zn}, 0.014 \% \mathrm{Ti}$ and the remaining $\mathrm{Al}$, was used for testing. The workpiece sizes were $150 \times 60 \times 4 \mathrm{~mm}$.

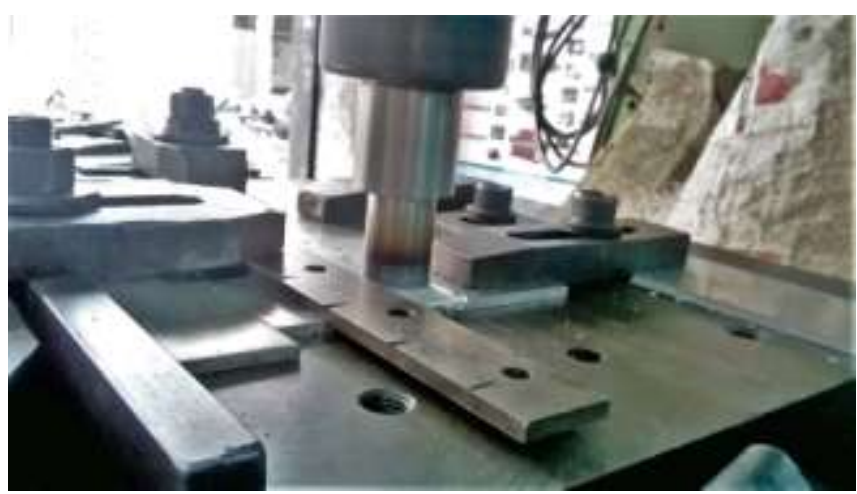

Fig - 4: While the plates were under friction stir processing

\section{RESULTS AND DISCUSSIONS}

In Friction stir welding of Aluminium alloy 5083, for each sample the following tests were conducted:

1) Tensile test 
2) Impact test

3) Vickers micro-hardness test

4) Microstructure

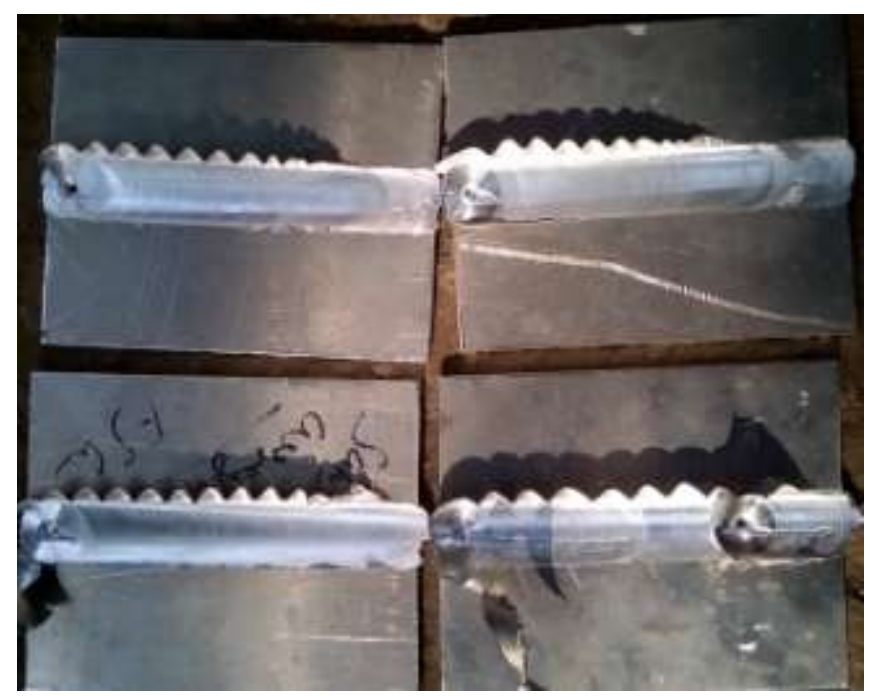

Fig -5: Aluminium 5083 plates after FSW

\subsection{Tensile Test}

Later than FSW all the specimens were experienced to come across out their ultimate tensile strength. Four specimens (pieces) were tested for each grouping of parameter and their most excellent joint values were considered. All the results were listed in the form of a bar chart ultimate tensile strength v/s Rotational speed as shown in fig. From the results of tensile test it can be studied that the ultimate tensile strength of the friction stir welded joint has been prejudiced by the tool profile of the welding tool.

Table -4: Mechanical properties at various tool revolution

\begin{tabular}{|l|l|l|l|l|}
\hline $\begin{array}{l}\text { Tool } \\
\text { rotation } \\
\text { speed(rpm) }\end{array}$ & $\begin{array}{l}\text { Tensile } \\
\text { stress } \\
\left(\mathrm{N} / \mathrm{mm}^{2}\right)\end{array}$ & $\begin{array}{l}\text { Impact } \\
\text { strength } \\
(\text { Joules })\end{array}$ & \%Elongation & $\begin{array}{l}\text { Yield } \\
\text { stress }\end{array}$ \\
\hline 900 & 202.875 & 26 & 14.20 & 122.016 \\
\hline 1120 & 203.502 & 24 & 12.40 & 132.181 \\
\hline 1400 & 168.755 & 26 & 8.20 & 94.193 \\
\hline 1800 & 109.494 & 24 & 2.60 & 94.193 \\
\hline
\end{tabular}

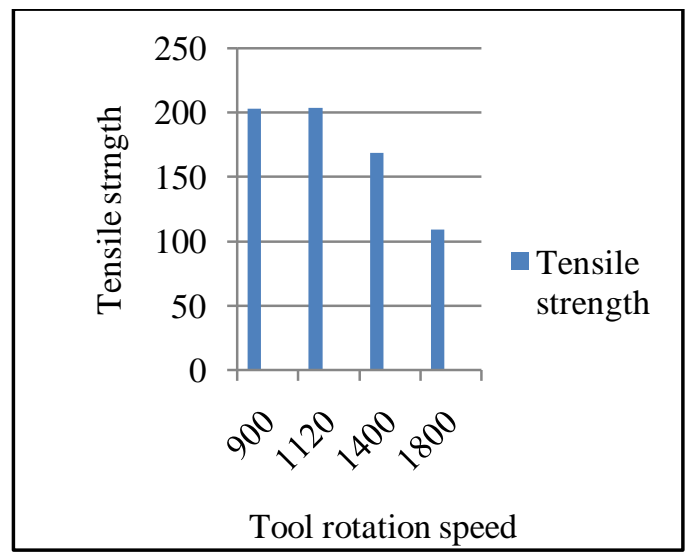

Chart -1: Tool rotation speed Vs Tensile strength

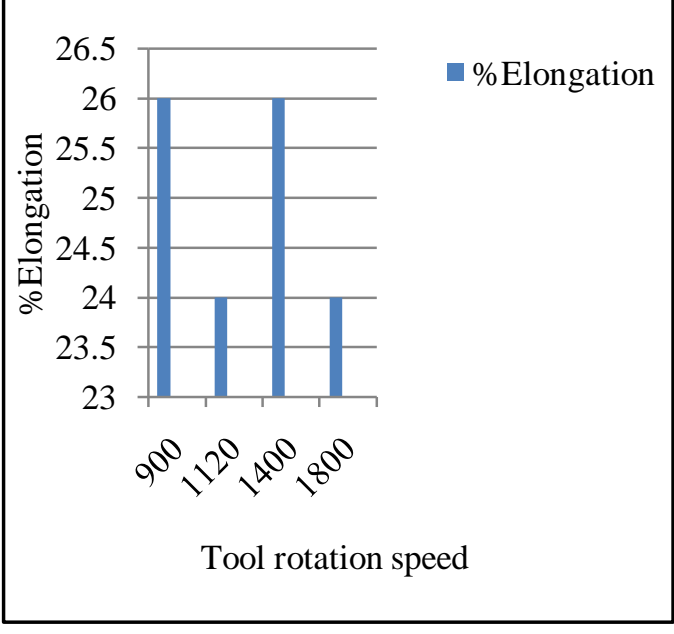

Chart - 2: Tool rotation speed Vs \%Elongation

1) From above drawn graphs it is to be clear that the ultimate tensile strength is more at a tool rotational speed of 1120rpm, because the heat input is sufficient at that condition and the grains were recrystallized and equi-axed.

2) From graph the $\%$ Elongation is more for 900rpm and 1400rpm i.e., 26\%. And it is less for 1120rpm and $1800 \mathrm{rpm}$.

3) The tensile strength obtained at moderate heat supply and by increasing the tool rotation speed the tensile strength decreases, due to the reason that the crystals are reallocated and there is a coarse grain structure obtained.

4) The conical threaded tool profile is in optimum at a tool rotation speed of $1120 \mathrm{rpm}$.

5) The best joint of friction stir welding of aluminium 5083 among four plates is at $1120 \mathrm{rpm}$ and at a welding speed of $40 \mathrm{~mm} / \mathrm{min}$.

\subsection{Vickers Micro Hardness}

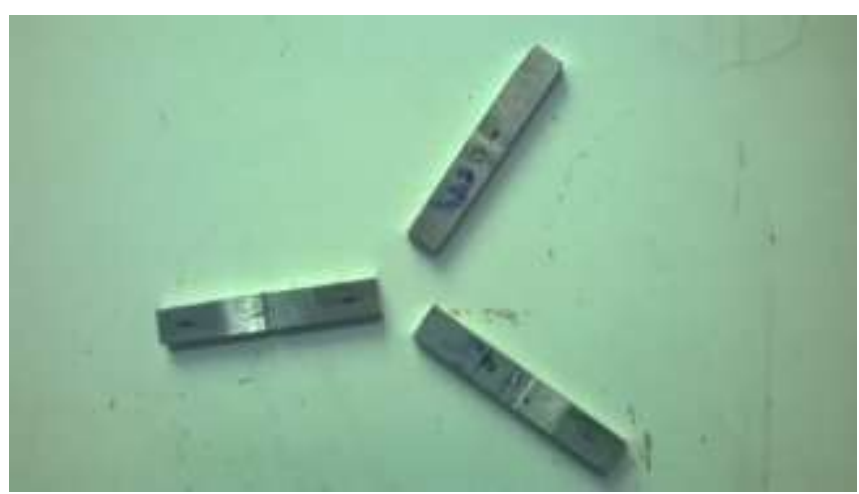

Fig - 6: Micro-hardness specimens

Vickers Micro hardness test is made to check the hardness of the weld samples. The micro hardness of Vickers is achieved great at $900 \mathrm{rpm}$ and the value is $97.93 \mathrm{Hv}$. And it is very less at $1800 \mathrm{rpm}$. 
Table - 5: Results showing micro-hardness

\begin{tabular}{|l|l|}
\hline Tool rotation speed $(\mathrm{rpm})$ & Hardness value $(\mathrm{Hv})$ \\
\hline 900 & 97.93 \\
\hline 1120 & 92.27 \\
\hline 1400 & 95.00 \\
\hline 1800 & 91.33 \\
\hline
\end{tabular}

\subsection{Impact Strength}

Charpy Impact test is done to test the sudden load strength of the welded zone at different tool rotation speeds.

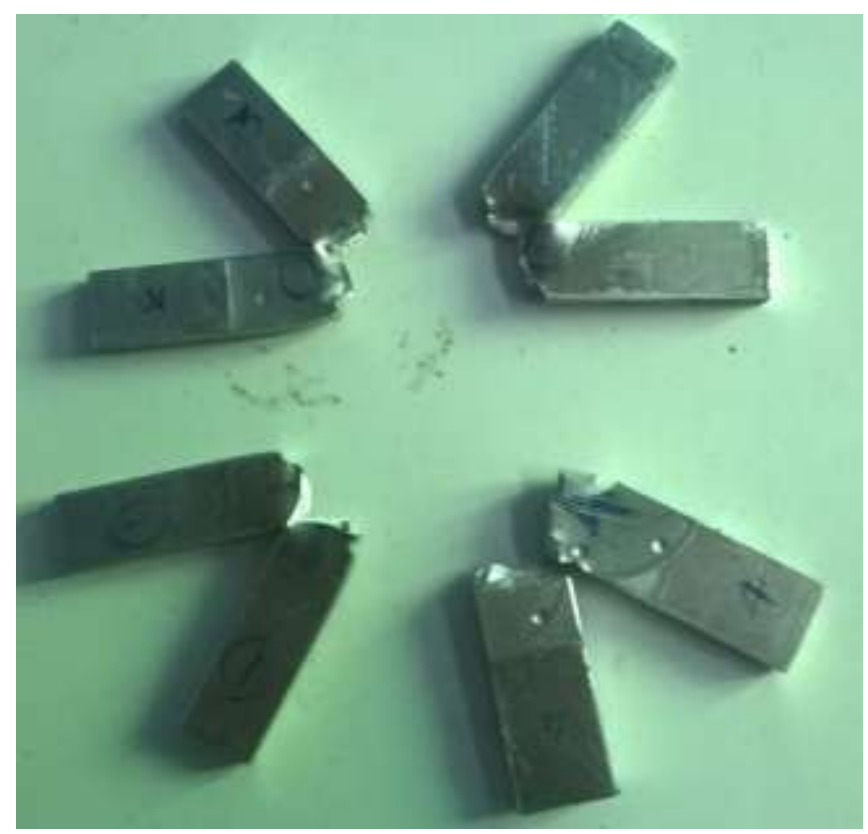

Fig - 7: Charpy Impact test specimens

From the results it was observed that the charpy impact strength maximum at $900 \mathrm{rpm}$ and at $1400 \mathrm{rpm}$.

\subsection{Microstructure Study}

The tool rotation speed is important factor that influence the microstructure grain size. The following observations were studied:

1). Microstructure Results - Effect of Welding on Structural Properties of AA5083 Assessment of structural properties at different zones of the weldments using optical microscope was carried out. Microstructure of base metal consists of fine precipitates of alloying elements disseminated in the matrix of aluminium solid solution. (a) And (b) figures shows that the microstructure is having fine grians and the strucuture shows that the grains are equi-axed and equally spaced.

2 ). The small size grains are obtained in case of tool rotation speed of $1120 \mathrm{rpm}$ as compared to 900rpm in correlation with Tensile strength properties. Small sized grains crosswise over entire weld shows that, high friction input is responsible for heating the weld over the temperature of recrystallization where the grain development happens. Uniform grain growth can be seen at 1120 speed.

3 ). From the microstructure study the figures (c) and (d) shows a very high coarse grain structure, i.e., the poor weld joint was obtained at these tool rotational speeds.

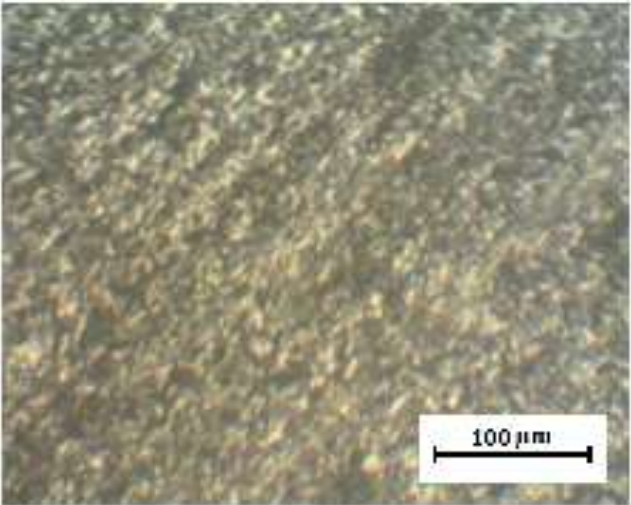

(a) $900 \mathrm{rpm}$

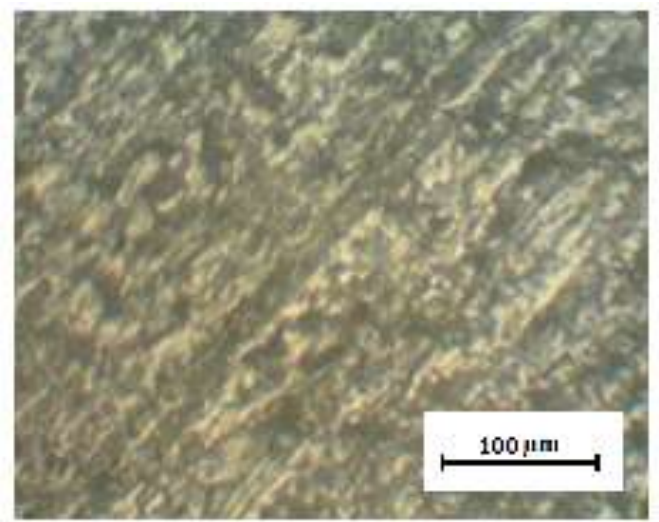

(b) $1120 \mathrm{rpm}$

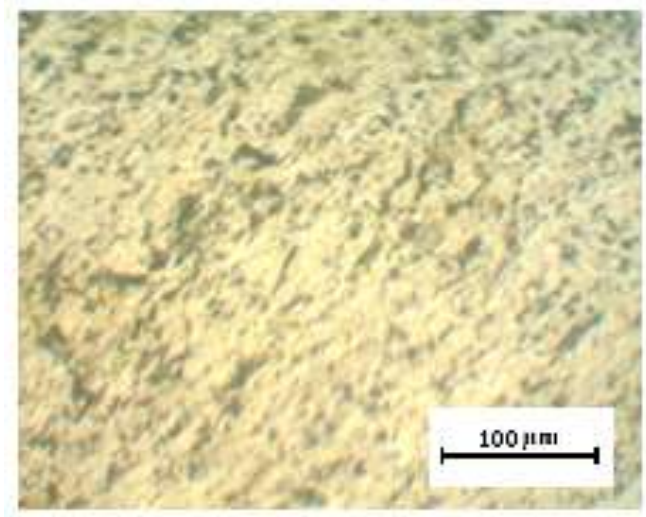

(c) $1400 \mathrm{rpm}$

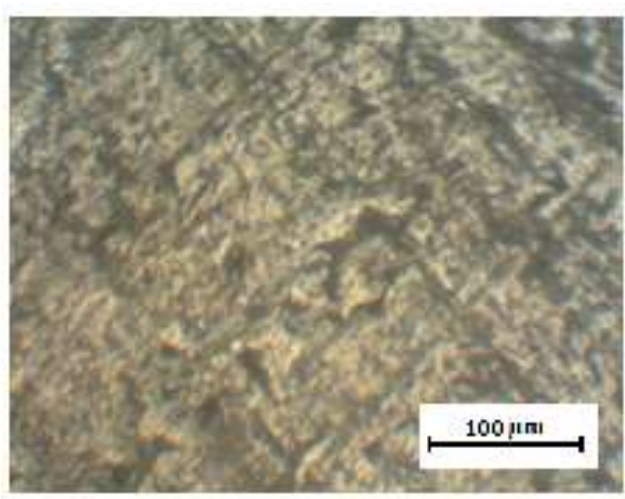

(d)1800rpm

Fig - 8: Microstructure images at different rotation speeds 


\section{CONCLUSION}

From the investigation, the following conclusions have been found that:

1) For Aluminium 5083, at $1120 \mathrm{rpm}$, by using conical threaded profile tool the mechanical properties obtained were optimum.

2) It has been observed that the variation in tensile strength occurs for different tool rotational speeds. The tensile strength is found to be grater at $1120 \mathrm{rpm}$ and less at $1400 \mathrm{rpm}$. This is because of having more friction generated at $1400 \mathrm{rpm}$ and the grains were totally disturbed and finally the coarse microstructure was obtained at $1800 \mathrm{rpm}$.

3) Assessment of structural properties at different zones of the weldments using optical microscope was carried out. Microstructure of the plate is best at $1120 \mathrm{rpm}$ with fine grain structure.

\section{REFERENCES}

[1]. Thomas W.M, Nicholas E.D, Needham J.C, Murch M.G, Temple smith P and Dawes C.J, Friction stir welding, International patent application No.PCT/GB92102203 and Great Britain patent application No.9125978.8, 1991.

[2]. R.S. Mishra, Friction Stir Welding and Processing, Materials Science and Engineering R, 50, Pp 1-78, 2005. International Scholarly and Scientific Research \& $\begin{array}{lll}\text { Innovation } & 10(1) & 2016\end{array}$ scholar.waset.org/1999.2/10003197 World Academy of Science, Engineering and Technology International Journal of Chemical, Molecular, Nuclear, Materials and Metallurgical Engineering Vol:10, No:1, 2016

[3]. M. Koilraj, V. Sundareswaran, S. Vijayan and S.R. Koteswara Rao, Friction stir welding of dissimilar aluminum alloys AA2219 to AA5083- Optimization of process parameters using Taguchi technique, Materials \& Design, Vol. 42, Pp 1-7, 2012.

[4]. N.T. Kumbhar and G.K. Dey and K. Bhanumurthy, Friction Stir Welding of Aluminium Alloys, Barc News letter, Issue no. 321, Pp 11-17, 2011.

[5]. T. DebRoy and H. Bhadeshia, Friction stir welding of dissimilar alloys-a perspective, Sci Technol Weld Joining, 15(4), Pp 266-270, 2010.

[6]. M. Peel, A. Steuwer, M. Preuss and P. J. Withers, Micro-structure, mechanical properties and residual stresses as a function of welding speed in aluminium AA5083 friction stir welds, Acta Materialia, 51, Pp 4791-4801, 2003. [7]. Maen M. Al-rashdan, Influence of friction stir welding process and tool shape on strength properties of aluminium alloy joints, Recent advances in Industrial and manufacturing technologies, ISBN: 978-1-61804-186-9, Pp 25-29.

[8]. S. Sattari, H. Bisadi, and M. Sajed, Mechanical Properties and Temperature Distributions of Thin Friction Stir Welded Sheets of AA5083, International Journal of Mechanics and Applications, 2(1), Pp 1-6, 2012.

[9]. L. Karthikeyan, M. Puviyarasan, S. Sharath kumar and B.Balamugundan, Experimental studies on Friction stir welding of AA2011 and AA6063 aluminium alloys, international journal of advanced engineering technology, e- issn 0976-3945, vol.iii, issue iv, Pp144-145, 2012.

[10]. L.V. Kamble, S.N. Soman and P.K. Brahmankar, Effect of Tool Design and Process Variables on Mechanical Properties and Microstructure of AA6101-T6 Alloy Welded by Friction Stir Welding, IOSR Journal of Mechanical and Civil Engineering, ISSN(e) : 2278-1684, ISSN(p) : 2320334X, Pp 30-35.

[11]. Ramaraju Ramgopal varma, Abdullah bin ibrahim, Mohammed, Arifpin bin mansor, Mechanical properties of the friction stir welded dissimilar aluminium alloy joints, proceedings of $3 \mathrm{rd}$ international conference, pune, ISBN: 978-93-82702-62-7, Pp 1-5, 2014. 